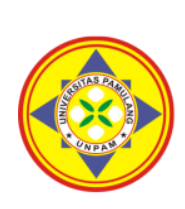

\title{
PENGARUH GAYA KEPEMIMPINAN DAN DISIPLIN KERJA TERHADAP KINERJA KARYAWAN PADA PT. CHAKRA LESTARI SEJAHTERA
}

\author{
${ }^{1 *}$ Yhonanda Harsono, ${ }^{2}$ Findi Widya Andriyani \\ Universitas Pamulang, Tangerang Selatan, Banten, Indonesia \\ *yhonanda2906@gmail.com
}

\begin{abstract}
Abstrak
Tujuan penelitian ini adalah untuk mengetahui pengaruh Gaya Kepemimpinan dan disiplin kerja terhadap Kinerja karyawan pada PT. Chakra Lestari Sejahtera baik secara parsial maupun secara simultan. Metode yang digunakan adalah metode deskriptif kuantitatif. Teknik sampling yang digunakan adalah random sampling menggunakan dengan sampel sebanyak 52 responden. Analisis data menggunakan uji validitas, uji reliabilitas, uji asumsi klasik, analisis regresi, analisis koefisien korelasi, analisis koefisien determinasi dan uji hipotesis. Hasil penelitian ini di dapat gaya kepemimpinan dan disiplin kerja berpengaruh positif terhadap kinerja karyawan dengan diperoleh persamaan regresi $\mathrm{Y}=9,759+0,495 \mathrm{X} 1+0,269 \mathrm{X} 2$. Uji hipotesis diperoleh nilai $\mathrm{F}$ hitung $>\mathrm{F}$ tabel atau $(28,603>2,790)$, hal tersebut juga diperkuat dengan probability signifikansi $0,000<0,05$. Dengan demikian $\mathrm{H} 0$ ditolak dan $\mathrm{H} 3$ diterima. Artinya terdapat pengaruh signifikan secara simultan antara gaya kepemimpinan dan disiplin kerja terhadap kinerja karyawan di PT. Chakra Lestari Sejahtera.
\end{abstract}

Kata Kunci : Gaya Kepemimpinan, Disiplin Kerja, Kinerja Karyawan.

\begin{abstract}
The purpose of this study was to determine the effect of leadership style and work discipline on employee performance at PT. Chakra Lestari Sejahtera either partially or simultaneously. The method used is descriptive quantitative method. The sampling technique used is random sampling using a sample of 52 respondents. Data analysis used validity test, reliability test, classical assumption test, regression analysis, correlation coefficient analysis, coefficient of determination analysis and hypothesis testing. The results of this study found that leadership style and work discipline had a positive effect on employee performance with the regression equation $Y$ $=9.759+0.495 X 1+0.269 X 2$. Hypothesis testing is obtained by the calculated F value $>F$ table or $(28.603>$ $2.790)$, this is also strengthened by a significance probability of $0.000<0.05$. Thus HO is rejected and H3 is accepted. This means that there is a simultaneous significant influence between leadership style and work discipline on employee performance at PT. Chakra Lestari Sejahtera.

Keywords: Leadership Style, Work Discipline, Employee Performance.
\end{abstract}

\section{PENDAHULUAN}

Transformasi adalah langkah awal yang saat ini sudah seringkali didengungkan dan sedang terjadi dalam berbagai dimensi kehidupan baik dalam kehidupan personal, masyarakat hingga dalam kehidupan berbangsa. Hal ini terlihat dari tumbuh dan kembangnya persaingan untuk berprestasi mencapai pada peran masing-masing, baik professional maupun pribadi. Dan hal ini harus disikapi secara positif sebagai landasan pacu seluruh pelaku kehidupan, agar pencapaian prestasi yang kompetitif dapat dilakukan dengan sikap mental yang tepat.
Perusahaan merupakan suatu organisasi yang mempunyai berbagai macam tujuan. Aktivitas suatu perusahaan dalam pencapaian tujuan tersebut diperlukan pengelolaan faktor-faktor produksi yang terdiri dari sumber daya alam, sumber daya manusia, modal, bahan baku, mesin, teknologi. Perusahaan harus selalu memperhatikan keterkaitan antara faktor-faktor produksi tersebut, dengan demikian perusahaan dituntut untuk dapat mengelola dengan sebaik-baiknya terutama dalam bidang sumber daya manusia sehingga mampu bekerja lebih efektif dan efisien. Suatu organisasi dapat berjalan 
efektif apabila fungsi-fungsi manajemen seperti perencanaan (planning), pengorganisasian (organizing), pengarahan (actuating) dan pengendalian (controlling) apabila semua itu berfungsi dengan baik, serta unsur-unsur penunjangnya tersedia dan memenuhi persyaratan.

Sumber daya manusia merupakan salah satu faktor yang ikut terlibat secara langsung dalam menjalankan kegiatan perusahaan dan berperang penting dalam meningkatkan kinerja perusahaan dalam mencapai tujuan yang telah ditetapkan, sebagaimana Hasibuan

menyapaikan bahwa tujuan tidak mungkin terwujud tanpa peran aktif karyawan meskipun alat-alat yang dimiliki perusahaan begitu canggihnya" Oleh karena itu keberhasilan suatu perusahaan tidak hanya tergantung dengan teknologi perusahaan saja namun juga tergantung pada aspek sumber daya manusia yang dimiliki oleh perusahaan. Sehingga suatu perusahaan membutuhkan sumber daya manusia yang potensial, baik pemimpin maupun karyawan dapat memberikan kontribusi yang baik dan melaksanakan tugas dengan optimal untuk mencapai tujuan perusahaan. Karena semua kegiatan perusahaan akan melibatkan tindakan sumber daya manusia yang ada didalamnya. Lebih lanjut Hasibuan (2016:12) juga menyampaikan bahwa "Manajemen merupakan ilmu dalam mengatur pemanfaatan sumber daya manusia secara efektif untuk mencapai suatu tujuan tertentu.

Chakralestari melengkapi

perkembangan bidang pengembangan modal insani yang saat ini menjadi pusat perhatian dalam sebuah kelompok masyarakat, organisasi dan bangsa. Dengan mengembangkan program- program Pelatihan (Training) dan ditindak lanjuti pada pasca Pelatihan (Coaching) maka kami pun secara tidak langsung menjadi Mitra (Partner) bagi klien mitra kerja dalam menumbuh kembangkan Modal Insani (Human Capital) yang menjadi pelaku dan penggerak organisasi.
Gaya kepemimpinan yang sesuai dengan keadaan perusahaan dan keinginan karyawan akan mendorong dalam peningkatan kinerja karyawan dalam pencapaian sasaran dan tujuan perusahaan. Dalam pelaksanaan kegiatannya para pemimpin mempunyai gaya tersendiri dalam proses untuk mempengaruhi dan mengarahkan karyawannya, sehinga diharapkan mau bersama-sama berusaha mencapai tujuan perusahaan melalui pelaksanaan pekerjaan yang telah ditentukan. Karena permasalahan yang dihadapi perusahaan bervariasi, maka para pemimpin dituntut untuk mampu menerapkan gaya kepemimpinannya yang bervariasi pula sesuai dengan keadaan yang dihadapi.

\section{TINJAUAN PUSTAKA}

1. Gaya Kepemimpinan

Menurut Hasibuan (2016:113) nerpendapat "Gaya kepemimpinan adalah cara seorang pemimpin mempengaruhi perilaku bawahan, agar mau bekereja sama dan bekerja secara produktif untuk mencapai tujuan organisasi". Dia harus mampu membina dan memotivasi bawahannya untuk bekerja sama dan bekerja secara efektif dalam mencapai sasaran perusahaan.

Berdasarkan beberapa pendapat diatas dapat disimpulkan bahwa gaya kepemimpinan adalah kemampuan untuk mempengaruhi, memotivasi dan membuat orang lain mampu memberikan kontribusi secara sukarela dalam upaya mencapai tujuan organisasi, karena menunjukan pemimpin dapat menjalankan perannya dalam menggerakan, mengarahkan dan mengkordinasikan berbagai faktor lainnya dalam organisasi dalam rangka mengingatkan kinerja organisasi.

2. Disiplin Kerja

Dari Menurut Sinungan (2014:145) menyatakan bahwa disiplin kerja sebagai sikap mental yang tercermin dalam perbuatan atau tingkahlaku perorangan, kelompok atau masyarakat berupa ketaatan (obedience) terhadap 
peraturan- peraturan atau ketentuan yang ditetapkan pemerintah atau etik, norma dan kaidah yang berlaku di masyarakat untuk tujuan tertentu.

Sedangkan menurut Siagian (2015:305) mengemukakan bahwa “Disiplin karyawan dalam manajemen sumber daya manusia berangkat dari pandangan bahwa tidak ada manusia yang sempurna, lepas dari kesalahan dan kekhilafan". Menurut Rivai (2015:825) "Disiplin kerja adalah suatu alat yang digunakan para manajer untuk berkomunikasi dengan karyawan agar mereka bersedia untuk mengubah suatu perilaku dan untuk meningkatkan kesadaran juga kesediaan seseorang agar mentaati semua peraturan dan norma sosial yang berlaku di suatu perusahaan".

Sejalan dengan Rivai, bagi Sintaasih \& Wiratama (2013:129), "Disiplin kerja adalah merupakan tindakan manajemen untuk mendorong kesadaran dan kesediaan para anggotanya untuk mentaati semua peraturan yang telah ditentukan oleh organisasi atau perusahaan dan normanorma sosial yang berlaku secara sukarela". Menurut

Setyaningdyah (2013:145) disiplin kerja adalah kebijakan bergeser individu untuk menjadi diri bertanggung jawab untuk mematuhi peraturan lingkungan (organisasi). Menurut Hasibuan (2016:193) mengemukakan bahwa kedisiplinan adalah kesadaran dan kesediaan seseorang mentaati semua peraturan perusahaan dan norma-norma sosial yang berlaku. Kesadaran adalah sikap seseorang yang secara sukarela mentaati semua peraturan dan sadar akan tugas dan tanggung jawabnya".

Dari beberapa pendapat diatas dsiplin kerja merupakan suatu bentuk upaya pegawai yang berusaha memperbaiki dan membentuk pengetahuan, sikap dan perilaku karyawan sehingga perilaku karyawan tersebut secara sukarela berusaha bekerja secara koperatif dengan para karyawan lain serta meningkatkan prestasi kerja.

3. Kinerja Karyawan

Istilah kinerja berasal dari kata job perfomance atau actual perfomance (prestasi kerja atau prestasi sesungguhnya yang dicapai oleh seseorang). Mangkunegara (2015:67) pengertian kinerja (prestasi kerja) adalah hasil kerja secara kualitas dan kuantitas yang dicapai oleh seorang pegawai dalam melaksanakan tugasnya sesuai dengan tanggung jawab yang diberikan kepadanya.

Sedangkan menurut Wibowo (2016:18) mengemukakan "Kinerja merupakan hasil pekerjaan yang mempunyai hubungan kuat strategis organisasi, kepuasan kenosumen dan memberikan kontribusi ekonomi". Sedangkan menurut Ratundo dan Sacket (2012:76) mendefinisikan "Kinerja adalah kegiatan yang mencakup semua tindakan atau perilaku yang dikontrol oleh individu dan memberi kontribusi pada pencapaian tujuan-tujuan perusahaan".

Pendapat serupa juga dikemukakan oleh Hariandja (2013:55) yang mengemukakan "Kinerja merupakan hasil kerja yang dihasilkan oleh karyawan atau karyawan atau perilaku nyata yang ditampilkan sesuai dengan perannya dalam organisasi. Mathis (2014:113) berpendapat "Kinerja adalah apa yang dilakukan atau tidak dilakukan oleh karyawan".

Dari beberapa pendapat tersebut dapat disimpulkan bahwa kinerja merupakan proses pencapaian tujuan organisasi dan hasil dari usaha sumber daya manusia itu sendiri dalam sebuah organisasi.

\section{METODE}

Populasi dalam penelitian ini berjumlah 52 responden seluruh karyawan PT. Chakra Lestari Sejahtera. Teknik pengambilan sampling dalam penelitian ini adalah sampel jenuh, dimana semua anggota populasi dijadikan sebagai sampel. 
Dengan demikian sampel dalam penelitian ini sampel yang digunakan berjumlah 88 responden. antara variabel independen terhadap variabel dependennya. Dalam menganalisis data digunakan uji validitas, uji reliabilitas, analisis regresi linier sederhana, analisis koefisien korelasi, analisis koefisien determinasi dan pengujian hipotesis. Jenis penelitian yang dipakai adalah asosiatif, dimana tujuannya adalah untuk mengetahui atau mencari keterhubungan

\section{HASIL DAN PEMBAHASAN}

Pembahasan deskriptif, dimaksudkan untuk eksplorasi dan klarifikasi mengenai fenomena atau kenyataan sosial, dengan jalan mendeskripsikan sejumlah variabel yang berkenaan dengan masalah yang diteliti.

1. Keadaan atau kriteria obyek yang diteliti berdasar pada variabel gaya kepemimpinan (X1).

Gaya kepemimpinan merupakan suatu cara, pola dan kemampuan tertentu yang digunakan oleh seorang pemimpin dalam bersikap, berkomunikasi dan berinteraksi untuk mempengaruhi, mengarahkan, mendorong dan mengendalikan orang lain atau bawahan agar bias melakukan suatu pekerjaan sehingga mencapai suatu tujuan. Keadaan atau kriteria secara keseluruhan untuk kuesioner variabel gaya kepemimpinan (X1) diperoleh rata-rata score 3.75 dengan kriteria baik. Dari keseluruhan pernyataan di atas, yang mendapatkan ratting score paling rendah adalah pernyataan pimpinan mau mendengarkan kritik dan saran yang disampaikan bawahan dimana hanya mencapai score 3,37.

2. Keadaan atau kriteria obyek yang diteliti berdasar pada variabel disiplin kerja (X2).

Disiplin kerja merupakan suatu sikap dan perilaku seseorang yang menunjukan ketaatan, kepatuhan, kesetiaan, keteraturan dan ketertiban pada peraturan perusahaan atau organisasi dan norma-norma sosial yang berlaku. Keadaan atau kriteria secara keseluruhan untuk kuesioner variabel disiplin kerja (X2) diperoleh rata-rata score 3.74 dengan kriteria baik. Dari keseluruhan pernyataan di atas, yang mendapatkan ratting score paling rendah adalah pernyataan penegakan peraturan diberlakukan tidak memihak, tanpa melihat posisi dan jabatan dimana hanya mencapai score 3,31 .

3. Keadaan atau kriteria obyek yang diteliti berdasar pada variabel kinerja karyawan (Y).

Kinerja merupakan hasil kerja secara kualitas dan kuantitas yang dcapai oleh seseorang karyawan dalam melaksanakan tugasnya sesuai dengan tanggung jawab yang diberikan kepadanya. Keadaan atau kriteria secara keseluruhan jawaban responden responden untuk kuesioner variabel kinerja karyawan (Y) diperoleh ratarata score 3.84 dengan kriteria baik. Dari keseluruhan pernyataan di atas, yang mendapatkan ratting score paling rendah adalah pernyataan saya selalu cepat tanggap terhadap tugas baru yang diberikan dimana hanya mencapai score 3,35

\section{KESIMPULAN DAN SARAN Kesimpulan}

Berdasarkan dari hasil penelitian dan pembahasan mengenai pengaruh gaya kepemimpinan dan disiplin kerja terhadap kinerja karyawan, maka dapat ditarik kesimpulan sebagai berikut :

1. Gaya kepemimpinan berpengaruh terhadap kinerja karyawan dengan nilai koefisien adj korelasi sebesar 0,466 artinya kedua variabel memiliki tingkat pengaruh yang sedang dengan koefisiendeterminasi nilai adj r-square sebesar $46,6 \%$. Uji hipotesis diperoleh $\mathrm{t}$ hitung $>\mathrm{t}$ tabel atau $(6,743>2,009)$, hal ini diperkuat dengan probability signifikansi $0,000<0,05$, dengan demikian $\mathrm{H} 0$ ditolak dan $\mathrm{H} 1$ diterima artinya terdapat pengaruh signifikan 
antara gaya kepemimpinan terhadap kinerja karyawan di PT. Chakra Lestari Sejahtera.

2. Disiplin kerja berpengaruh terhadap kinerja karyawan dengan nilai koefisien adj korelasi sebesar 0,269 artinya kedua memiliki tingkat pengaruh yang rendah dengan koefisien determinasi nilai adj r-square sebesar $26,9 \%$. Uji hipotesis diperoleh $\mathrm{t}$ hitung $>\mathrm{t}$ tabel atau $(4,441>$ 2,009), hal ini diperkuat dengan probability signifikansi $0,000<0,05$, dengan demikian $\mathrm{H} 0$ ditolak dan $\mathrm{H} 2$ diterima artinya terdapat pengaruh signifikan antara disiplin kerja terhadap kinerja karyawan $(\mathrm{Y})$ di PT. Chakra Lestari Sejahtera.

3. Gaya kepemimpinan dan disiplin kerja berpengaruh terhadap kinerja karyawan dengan persamaan regresi $Y$ $=9,759+0,495 \times 1+0,269 \times 2$. Uji hipotesis diperoleh nilai $\mathrm{F}$ hitung $>\mathrm{F}$ tabel atau $(28,603>2,790)$, hal tersebut juga diperkuat dengan probability signifikansi $0,000<0,05$. Dengan demikian $\mathrm{H} 0$ ditolak dan $\mathrm{H} 3$ diterima. Artinya terdapat pengaruh signifikan secara simultan antara gaya kepemimpinan dan disiplin kerja terhadap kinerja karyawan di PT. Chakra Lestari Sejahtera.

\section{Saran}

Berdasarkan kesimpulan hasil penelitian mengenai pengaruh gaya kepemimpinan dan disiplin kerja terhadap kinerja karyawan di PT. Chakra Lestari Sejahter, peneliti mengajukan saran yang dapat dijadikan solusi dari pembahasan dan dapat dijadikan bahan pertimbangan bagi manajemen perusahaan dalam mengambil kebijakan manajemennya.

1. Variabel gaya kepemimpinan pernyataan yang paling lemah ada pada nomor 10 yaitu. Pimpinan mau mendengarkan kritik dan saran yang disampaikan bawahan dimana hanya mencapai score sebesar 3,37. Untuk lebih baik lagi pimpinan harus dengan kerendahan hati mau mendengarkan masukan yang konstruktif dari bawahan agar komunikasi kerja dibangun lebih baik lagi serta mampu menerima kritikan dari bawahan agar pimpinan dapat memperbaiki komunikasi dengan bawahan.

2. Variabel disiplin kerja pernyataan yang paling lemah ada pada nomor yaitu. Penegakan peraturan diberlakukan tidak memihak, tanpa melihat posisi dan jabatan dimana hanya mencapai score sebesar 3,31. Untuk lebih baik lagi perusahaan sebaiknya tegas terhadap karyawan yang melanggar aturan perusahaan agar semua karyawan merasa mendapatkan keadilan serta tidak memandang posisi karyawan yang bilamana karyawan tersebut melanggar peraturan diperusahaan.

3. Variabel kinerja karyawan pernyataan yang paling lemah ada pada nomor 3 yaitu. Saya selalu cepat tanggap terhadap terhadap tugas baru yang diberikan dimana hanya mencapai score sebesar 3,35. Untuk lebih baik lagi sebaiknya pimpinan memberikan instruksi atau arahan yang jelas kepada karyawan atas tugas baru yang diberikan agar dapat tersampaikan dengan jelas oleh karyawan. Dan sebaiknya karyawan mendapatkan tugas sesuai dengan jobdesknya.

\section{DAFTAR PUSTAKA}

A.A. Anwar Prabu Mangkunegara, 2017. Evaluasi Kinerja SDM. Bandung: PT. Refika Aditama.

Agustin, F. (2021). Pengaruh Gaya Kepemimpinan Terhadap Kinerja Karyawan Pada PT. Gama Panca Makmur Di Tangerang. JENIUS (Jurnal Ilmiah Manajemen Sumber Daya Manusia), 4(2), 128-136.

Algifari. (2015). Analisis Regresi untuk Bisnis dan Ekonomi. Yogyakarta: BPFE.

Anoraga Panji, 2014. Psikologi Kerja. Jakarta : PT Rineka Cipta.

Ardana, I Komang dkk. 2012.ManajemenSumber Daya Manusia. Yogyakarta:Graha ilmu Arikunto, Suharsimi. 2014. Prosedur 
Penelitian Suatu Pendekatan Praktik. Jakarta : Rineka Cipta.

Bateman, Thomas S. dan Scott A. Snell. 2008. Manajemen. Edisi 7-buku 1. Diterjemahkan oleh Chriswan Sungkono dan Ali Akbar Yulianto. Jakarta: Salemba Empat.

Edy,Sutrisno,(2016),Manajemen Sumber Daya Manusia, Kencana Prenada Media Group, Jakarta.

Feriyanto, Andri dan Shyta, Endang Triana. 2015. Pengantar

Ghozali, Imam. 2018. AplikasiAnalisis Multivariate dengan Program IBM SPSS 25. Badan Penerbit Universitas Diponegoro: Semarang

Hariandja, 2012,Manajemen Sumber Daya Manusia, Grasindo, Jakarta.

Hasibuan, Malayu S.P. 2016.Manajemen Sumber Daya Manusia.

EdisiRevisi. Jakarta: Penerbit PT Bumi Aksara.

Kristianti, L. S., et al (2021). Pengaruh Motivasi Dan Disiplin Kerja Terhadap Kinerja Pegawai Pada

Robbins, P. Stephen, Mary Coulter.2014.Management.

Twelfth Edition.United States: Pearson Education Limited.

Safroni, Ladzi. 2013. Manajemen dan Reformasi Pelayanan Publik dalam Konteks Birokrasi Indonesia. Surabaya : Aditya Media Publishing

Sudarso, A. P. (2017). Analisis Pengaruh Gaya Kepemimpinan Dan Insentif
Dinas Pariwisata Purwakarta. Jurnal Ilmiah PERKUSI, 1(1), 101-109.

Malhotra, N.K., 2009, Riset Pemasaran, Edisi keempat, Jilid 1, PT Indeks, Jakarta

Mathis, Robert \& H. Jackson, John. 2011. Human Resource Management (edisi 10). Jakarta : Salemba Empat.

Nurjaya, N., et al (2020). The Effect of Work Stress and Work Conflict on Employees Turnover Intention In Middle Small Micro Enterprises (MSMEs) In South Tangerang Region. International Journal of Educational Administration, Management, and Leadership, 51-62. (2021). Pengaruh Etos Kerja Dan Disiplin Kerja Terhadap Kinerja Pegawai Pada Dinas Kehutanan Dan Perkebunan Kota Bogor. JENIUS (Jurnal Ilmiah Manajemen Sumber Daya Manusia), 4(2), 172-184.

Rivai, Veithzal, “Manajemen Sumber Daya Manusia Untuk Perusahaan", Raja Grafindo Persada, Jakarta, 2015. Terhadap Kinerja Karyawan Pada Yayasan Pendidikan Mulia Buana. JENIUS (Jurnal Ilmiah Manajemen Sumber Daya Manusia), 1(1).

Suherman, H. (2018). Pengaruh Gaya Kepemimpinan Dan Disiplin Kerja Terhadap Kinerja Karyawan PT. Selaras Karya Raya Jakarta. JENIUS (Jurnal Ilmiah Manajemen Sumber Daya Manusia), 2(1). 